\title{
ANALISIS PERHITUNGAN DAN PELAPORAN \\ PPH FINAL PASAL 4 AYAT 2 ATAS BUNGA DEPOSITO DAN TABUNGAN NASABAH \\ PADA PT. BPR MAPALUS TUMETENDEN CABANG TOMOHON
}

\author{
Veronica Junisa Lolong \\ David Paul Elia Saerang \\ Hence Wokas
}

Fakultas Ekonomi dan Bisnis, Jurusan Akuntansi

Universitas Sam Ratulangi Manado

email: vicca.vicco@yahoo.com

\begin{abstract}
Income tax is one of the largest government revenues. Income Tax Law Article 4 Paragraph 2 gives a mandate to the government to impose income tax on certain earnings final. This study aims to determine how the interest calculation and interest reports and final income tax deduction on interest of savings and customer deposits at PT. BPR Mapalus Tumetenden Branch Tomohon. Descriptive analysis was employed in this study. Data were obtained by field studies. The results shows that the calculation and reports of Final Income Tax Article 4 Paragraph 2 on deposit and savings PT. BPR Mapalus Tumetenden Branch Tomohon have compiled with the laws of regulations. Leaders of PT. BPR Mapalus Tumetenden Branch Tomohon should improve the service quality to each customer, so that the customers can increase the amount of savings in bank.
\end{abstract}

Keywords: calculation, reporting, deposit interest, customer savings 


\section{PENDAHULUAN}

\section{Latar Belakang}

Pembangunan di Indonesia sangatlah penting untuk mensejahterakan masyarakat. Pembangunan tidak akan tercapai apabila tidak ada kerja sama antara pemerintah dan masyarakat. Membayar pajak merupakan salah satu kewajiban warga Negara didalam turut serta memelihara kelangsungan hidup berbangsa dan bernegara. Adriani (2011:3) menjelaskan bahwa pajak adalah iuran masyarakat kepada Negara yang terutang oleh yang wajib membayarnya menurut peraturanperaturan umum (undang-undang) dengan tidak mendapat prestasi kembali yang langsung dapat ditunjuk dan yang gunanya adalah untuk membiayai pengeluaran-pengeluaran umum berhubung tugas Negara untuk menyelenggarakan pemerintahan.

Penerimaan Pajak Penghasilan (PPh) merupakan salah satu penerimaan terbesar dari penerimaan Negara. Penerimaan $\mathrm{PPh}$ ini diharpkan dapat terus meningkat seiring dengan pertumbuhan dunia usaha nasional. Untuk itu pemerintah mulai melaksanakan suatu terobosan yaitu dengan menerapkan sistem PPh yang bersifat final. Undang-Undang Pajak Penghasilan Pasal 4 ayat 2 memberikan mandat kepada pemerintah untuk mengenakan $\mathrm{PPh}$ final atas penghasilan-penghasilan tertentu.

Bank Perkreditan Rakyat (BPR) adalah salah satu pendukung perkembangan informal. Peran BPR dalam pemberian kredit bagi usaha mikro kecil dan menengah ini dapat membantu menciptakan lapangan pekerjaan, pemerataan pendapatan, dan pemerataan kesempatan berusaha di Indonesia. PT. BPR Mapalus Tumetenden Cabang Tomohon adalah salah satu PT. BPR yang ada di Sulawesi Utara yang termasuk dalam kategori perusahaan sehat dari segi manajemen menurut penilaian Bank Indonesia dan merupakan lembaga keuangan bank yang merupakan perusahaan swasta yang bergerak di bidang pelayanan simpanan dalam bentuk tabungan dan deposito.

\section{Tujuan Penelitian}

Tujuan dari penelitian ini yaitu untuk mengetahui bagaimanakah perhitungan, pemotongan, penyetoran, dan pelaporan bunga deposito dan tabungan nasabah serta apakah perhitungan dan pelaporan PPh final pasal 4 ayat 2 atas bunga deposito dan tabungan nasabah pada PT. BPR Mapalus Tumetenden Cabang Tomohon telah sesuai dengan undang-undang perpajakan yang ada.

\section{Konsep Akuntansi}

\section{TINJAUAN PUSTAKA}

Menurut Herduard (2015), akuntansi merupakan suatu proses, artinya dari data mentah menjadi informasi yang siap dipakai, didalamnya terdapat berbagai kegiatan yaitu pengumpulan, pengidentifikasian, pencatatan, serta pengikhtisaran dari data keuangan, data keuangan yang telah diikhtisarkan merupakan informasi keuangan yang disampaikan kepada para pemakai yang kemudian akan ditafsirkan untuk kepentingan pengambilan keputusan ekonomi. Hery (2013:4) menjelaskan bahwa akuntansi adalah pengukuran, penjabaran, atau pemberian kepastian mengenai informasi yang akan membantu manajer, investor, otoritas pajak dan pembuat keputusan lain untuk membuat alokasi sumber daya keputusan didalam perusahaan, organisasi dan lembaga pemerintah. Definisi Akuntansi menurut American Accounting Association adalah proses pengidentifikasian, pengukuran, dan pelaporan informasi ekonomi guna memungkinkan diadakannya penilaian dan pengambilan keputusan oleh pemakai informasi tersebut. 


\section{Akuntansi Perpajakan}

Akuntansi Pajak adalah akuntansi yang diterapkan dengan tujuan untuk menetapkan besarnya pajak terutang. Menurut Supriyanto (2011:20) akuntansi perpajakan adalah suatu proses pencatatan, penggolongan dan pengikhtisaran suatu transaksi keuangan kaitannya dengan kewajiban perpajakan dan diakhiri dengan pembuatan laporan keuangan fiskal sesuai dengan ketentuan dan peraturan perpajakan yang terkait sebagai dasar pembuatan Surat Pemberitahuan Tahunan. Sukrisno Agoes (2010:7) menyatakan bahwa akuntansi perpajakan merupakan bagian dari akuntansi komersial, akuntansi pajak tidak memiliki standar seperti akuntansi komersial yang diatur dalam Standar Akuntansi Keuangan (SAK). Fungsi Akuntansi Perpajakan adalah berfungsi mengolah data kuantitatif yang akan digunakan untuk menyajikan laporan keuangan yang memuat oerhitungan perpajakan, yang kemudian akan digunakan sebagai pertimbangan pengambilan keputusan. Oleh sebab itu maka akuntansi harus memenuhi tujuan kualitatif. Tujuan kualitatif dalam Akuntansi Perpajakan adalah relevan, dapat dimengertim daya uji, netral, tepat waktu, daya banding, lengkap.

\section{Konsep Perpajakan}

Menurut Mardiasmo (2011:1) pajak adalah iuran rakyat kepada kas Negara berdasarkan Undang-Undang (yang dapat dipaksakan) dengan tiada mendapat jasa timbal (kontra prestasi) yang langsung dapat ditunjukkan dan yang digunakan untuk membayar pengeluaran umum. Harnanto (2013:1) menyatakan pajak adalah pembayaran atau pembebanan yang tidak secara langsung berhubungan dengan barang/jasa yang berada dalam wilayah atau dalam jangkauan pemerintah.

\section{Fungsi Pajak}

Fungsi utama pajak adalah mengisi kas Negara sebanyak mungkin. Menurut Mardiasmo (2011:1) Fungsi pajak terbagi dua, yaitu:

1. Fungsi Budgetair yaitu pajak sebagai sumber dana bagi pemerintah untuk membiayai pengeluaran-pengeluaran.

2. Fungsi Mengatur (Regulerend) yaitu pajak sebagai alat untuk mengatur atau melaksanakan kebijaksanaan pemerintah dalam bidang social dan ekonomi.

\section{Syarat Pemungutan Pajak}

Menurut Mardiasmo (2011:2) syarat pemungutan pajak:

1. Pemungutan pajak harus adil (Syarat Keadilan)

2. Pemungutan pajak harus berdasarkan Undang-Undang (Syarat Yuridis)

3. Tidak mengganggu perekonomian (Syarat Ekonomis)

4. Pemungutan pajak harus efisien (Syarat Finansial)

5. Sistem pemungutan pajak harus sederhana

\section{Sistem Pemungutan Pajak}

Menurut Mardiasmo (2011:7) sistem pemungutan pajak:

1. Official assessment system

Adalah suatu sistem pemungutan yang memberi wewenang kepada pemerintah (fiskus) untuk menentukan besarnya pajak yang terutang oleh Wajib Pajak.

2. Self assessment system

Adalah suatu sistem pemungutan yang memberi wewenang kepada wajib pajak untuk menentukan sendiri besarnya pajak terutang.

3. Withholding system 
Adalah suatu sistem pemungutan yang memberi wewenang kepada pihak ketiga (bukan fiskus dan bukan wajib pajak yang bersangkutan) untuk menentukan besarnya pajak yang terutang oleh Wajib Pajak.

\section{Pajak Penghasilan}

Undang-Undang Pajak Penghasilan (PPh) mengatur pengenaan Pajak Penghasilan terhadap subjekpajak berkenaan dengan penghasilan yang diterima atau diperolehnya dalam tahun pajak. Subjek pajak tersebut dikenai pajak apabila menerima atau memperoleh penghasilan. Subjek pajak yang menerima atau memperoleh penghasilan dalam Undang-Undang PPh disebut Wajib Pajak. Wajib pajak dikenai pajak atas penghasilan yang diterima atau diperolehnya selama satu tahun pajak atau dapat pula dikenai pajak untuk penghasilan dalam bagian tahun pajak, apabila kewajiban pajak subjektifnya dimulai atau berakhir dalam tahun pajak. (Mardiasmo, 2011:135).

\section{Pajak Penghasilan Final Pasal 4 ayat 2}

Pajak Penghasilan Pasal 4 ayat 2 adalah pajak atas penghasilan sebagai berikut:

1. Penghasilan berupa bunga deposito dan tabungan lainnya, bunga obligasi dan surat utang Negara, dan bunga simpanan yang dibayarkan oleh koperasi kepada anggota koperasi orang pribadi;

2. Penghasilan berupa hadiah undian;

3. Penghasilan dari transaksi saham dan sekuritas lainnya, transaksi derivatif yang diperdagangkan di bursa, dan transaksi penjualan saham atau pengalihan penyertaan modal pada perusahaan pasangannya yang diterima oleh perusahaan modal ventura;

4. Penghasilan dari transaksi pengalihan harta berupa tanah dan/atau bangunan, usaha jasa konstruksi, usaha real estate, dan persewaan tanah dan/atau bangunan;

5. Penghasilan tertentu lainnya, yang diatur dengan atau berdasarkan Peraturan Pemerintah.

Pengenaan Pajak Penghasilan atas bunga deposito dan tabungan serta Diskonto Sertifikat Bank Indonesia (SBI) adalah sebagai berikut:

1. Dikenakan pajak final sebesar 20\% (dua puluh persen) dari jumlah bruto, terhadap Wajib Pajak dalam negeri dan Bentuk Usaha Tetap.

2. Dikenakan pajak final sebesar $20 \%$ (dua puluh persen) dari jumlah bruto atau dengan tariff berdasarkan Perjanjian Penghindaran Pajak Berganda yang berlaku, terhadap Wajib Pajak luar negeri.

Pemotongan pajak penghasilan pasal 4 ayat 2 tidak dilakukan terhadap:

1. Bunga dari deposito dan tabungan serta diskonto sertifikat Bank Indonesia sepanjang jumlah deposito dan tabungan serta sertifikat Bank Indonesia tersebut tidak melebihi Rp. 7.500.000,- dan bukan merupakan jumlah yang dipecah-pecah.

2. Bunga dan diskonto yang diterima atau diperoleh bank yang didirikan di Indonesia atau cabang bank luar negeri di Indonesia.

\section{Dasar Hukum PPh Final Pasal 4 ayat 2:}

1. PP 131 Tahun 2000 (berlaku sejak 1 Januari 2001) tentang PPh atas bunga deposito dan tabungan serta diskonto SBI.

2. KMK-51/KMK.04/2001 (berlaku sejak 1 Januari 2001) tentang pemotongan $\mathrm{PPh}$ atas bunga deposito dan tabungan serta diskonto SBI.

3. SE-29/PJ.43/2001 (berlaku sejak 1 Januari 2001) tentang pengawasan pemotongan, penyetoran, dan pelaporan Pajak Penghasilan Final atas Bunga Deposito dan Tabungan serta Diskonto Bank Indonesia (SBI). 


\section{Objek PPh Final Pasal 4 ayat 2}

Penghasilan berupa bunga deposito dan tabungan serta diskonto Sertifikat Bank Indonesia (SBI) termasuk bunga yang diterima atau diperoleh dari deposito dan tabungan yang ditempatkan dari luar negeri melalui bank yang didirikan atau berkedudukan di Indonesia atau cabang bank luar negeri di Indonesia.

\section{Jatuh Tempo PPh Final Pasal 4 ayat 2:}

PPh Pasal 4 ayat 2 yang dipotong oleh pemotong Pajak Penghasilan harus disetor paling lama tanggal 10 bulan berikutnya setelah masa pajak berakhir kecuali ditetapkan oleh Menteri Keuangan. PPh Pasal 4 ayat 2 yang harus dibayar sendiri oleh Wajib Pajak harus disetor paling lama 15 bulan berikutnya setelah masa pajak.

\section{Pemotong PPh Final Pasal 4 ayat 2:}

1. Bank Pembayar Bunga;

2. Koperasi;

3. Penyelenggara kegiatan;

4. Otoritas bursa;

5. Bendaharawan.

\section{Penerima Penghasilan Yang Dipotong PPh Final Pasal 4 ayat 2}

1. Penerima bunga deposito dan tabungan lainnya, bunga obligasi dan surat utang Negara, dan bunga simpanan yang dibayarkan oleh koperasi kepada anggota koperasi orang pribadi;

2. Penerima hadiah undian;

3. Penjual saham dan sekuritas lainny;

4. Pemilik properti berupa tanah dan/atau bangunan.

\section{Penelitian Terdahulu}

Mokoagow (2015) dalam penelitian yang berjudul analisis perhitungan PPh Final Pasal 4 ayat 2 atas bunga deposito dan tabungan nasabah pada PT. Bank Sulut Cabang Kotamobagu, Tujuan penelitian ini adalah untuk mengetahui bagaimanakah perhitungan bunga serta pemotongan PPh Final Pasal 4 ayat 2 atas bunga deposito dan tabungan nasabah pada PT. Bank Sulut Cabang Kotamobagu. Penelitian ini dilakukan dengan metode deskriptif. Hasil penelitian menunjukkan perhitungan $\mathrm{PPh}$ Final pasal 4 ayat 2 atas bunga deposito dan tabungan nasabah PT. Bank Sulut Cabang Kotamobagu telah sesuai dengan peraturan perundang-undangan yang ada. Persamaan dalam penelitian ini juga membahas tentang PPh Final Pasal 4 ayat 2 atas bunga deposito dan tabungan nasabah. Perbedaan dalam penelitian ini adalah objek penelitian yang berbeda. Hakim F (2015) dalam penelitian yang berjudul analisis penerapan PP No. 46 Tahun 2013 tentang Pajak Penghasilan UMKM terhadap tingkat pertumbuhan Wajib Pajak dan penerimaan PPh Pasal 4 ayat 2 pada KPP Pratama Manado, Tujuan penelitian ini adalah untuk mengetahui besarnya pertumbuhan wajib pajak selama tujuh belas bulan sebelum dan setelah penerapan PP No. 46 Tahun 2013 dan juga untuk menjelaskan penerimaan terhadap PPh Pasak 4 ayat 2 di wilayah kerja KPP Pratama Manado. Penelitian ini dilakukan dengan metode deskriptif. Hasil penelitian menunjukkan bahwa setelah penerapan PP No. 46 Tahun 2013 mengalami penurunan pertumbuhan wajib pajak sebesar $0,23 \%$ sedangkan rata-rata penerimaan $\mathrm{PPh}$ Pasal 4 ayat 2 dari PPh UMKM selama 17 bulan sejak pelaksanaan PP No. 46 Tahun 2013 adalah sebesar 3,89\% dengan kriteria sangat kurang. Persamaan dalam penelitian ini adalah menggunakan metode yang sama yaitu metode deskriptif. Perbedaan dalam penelitian ini adalah pembahasannya dimana penelitian ini membahas tentang penerimaan PPh Pasal 4 ayat 2. 


\section{Jenis Penelitian}

\section{METODE PENELITIAN}

Jenis penelitian dalam penelitian ini adalah Penelitian Deskriptif dimana peneliti secara langsung mendatangi objek penelitian yaitu PT. BPR Mapalus Tumetenden Cabang Tomohon untuk memperoleh data-data dan informasi yang. Menurut Basirun (2009:5), penelitian deskriptif adalah salah satu jenis penelitian yang tujuannya untuk menyajikan gambaran cara sistematis dan akurat mengenai fakta, sifat dari hubungan antar fenomena yang diteliti pada suatu perusahaan.

\section{Tempat dan Waktu Penelitian}

Dalam penelitian tempat atau lokasi penelitian sangat penting untuk mengetahui letak yang sebenarnya. Lokasi yang diteliti untuk mendapatkan hasil yang dimanfaatkan, dalam hal ini adalah PT. Bank Perkreditan Rakyat (BPR) Mapalus Tumetenden Cabang Tomohon, Jl. Raya Tomohon Kel. Walian Lingkungan 3 No. 56, Tomohon, Sulawesi Utara. Penelitian dilakukan pada bulan Februari April 2016.

\section{Prosedur Penelitian}

1. Permohonan mengadakan penelitian pada PT. Bank Perkreditan Rakyat Mapalus (BPR) Tumetenden Cabang Tomohon.

2. Melakukan wawancara dengan pihak perusahaan dan meminta data yang diperlukan.

3. Mengevaluasi dan menganalisis data yang telah dikumpulkan. Dan membandingkan sesuai atau tidak dengan perhitungan dan pelaporan Undang-Undang Perpajakan.

\section{Metode Pengumpulan Data}

Jenis data yang dikumpulkan dalam penelitian ini adalah data kualitatif. Menurut Soeratno (2008:64), data kualitatif ialah serangkaian observasi kemungkinannya tidak dapat dinyatakan dalam angka-angka.

\section{Teknik Pengumpulan Data}

1. Wawancara (Interview) yaitu teknik pengumpulan data dengan cara melakukan Tanya jawab secara langsung dengan pihak yang berwewenang untuk mendapatkan data-data sebagai bahan penelitian.

2. Dokumentasi yaitu teknik pengumpulan data dengan melihat atau menganalisis dokumendokumen yang dibuat oleh subjek sendiri atau oleh orang lain tentang subjek.

3. Studi Kepustakaan yaitu teknik pengumpulan data dengan cara mempelajari dan mendalami serta mengintip teori-teori atau konsep dari sebuah literatur baik buku ataupun lainnya yang berkaitan dengan permasalahan yang akan penulis angkat dan teliti.

\section{Metode Analisis}

Metode analisis data yang dilakukan dalam penelitian ini adalah metode deskriptif. Metode deskriptif adalah metode analisis dengan terlebih dahulu mengumpulkan data yang ada kemudian diklarifikasi, dianalisis, selanjutnya diiterprestasikan sehingga dapat memberikan gambaran yang jelas mengenai keadaan yang diteliti.

Teknik analisis dalam penelitian ini yaitu:

1. Mengumpulkan data dan informasi tentang Pajak Penghasilan (PPh) Pasal 4 ayat 2.

2. Mempelajari dan mengkaji data dan informasi tentang Pajak Penghasilan Pasal 4 ayat 2.

3. Menguraikan perhitungan, pemotongan, penyetoran, dan pelaporan Pajak Penghasilan (PPh)

Pasal 4 ayat 2. 
4. Menganalisis perhitungan, pemotongan, penyetoran, dan pelaporan sesuai dengan ketentuan perpajakan.

5. Menarik kesimpulan atas uraian dan penjelasan yang telah dilakukan.

\section{Hasil Penelitian}

\section{HASIL PENELITIAN DAN PEMBAHASAN}

Peraturan Pemerintah Nomor 131 Tahun 2000, tentang Pajak Penghasilan atas bunga deposito dan tabungan serta diskonto Sertifikat Bank Indonesia yaitu tarif pajak penghasilannya adalah sebesar $20 \%$ yang pengenaan pajaknya bersifat final.

Tabel.1 Suku Bunga Tabungan BPR Mapalus Tumetenden Cabang Tomohon

\begin{tabular}{llll}
\hline Rp. $\quad 500.000$ & - & Rp. 10.000 .000 & $6 \%$ \\
Rp. 10.000 .000 & - & Rp. 100.000 .000 & $6 \%$ \\
Rp. 100.000 .000 & - & Rp. 500.000 .000 & $6 \%$ \\
$>$ Rp. 500.000 .000 & & & $6 \%$ \\
\hline
\end{tabular}

Sumber: PT. BPR Mapalus Tumetenden Cabang Tomohon

Tabel. 2 Suku Bunga Deposito PT. BPR Mapalus Tumetenden Cabang Tomohon

$\begin{array}{ll}\text { 1 Bulan } & : 10 \% \\ 3 \text { Bulan } & : 10 \% \\ 6 \text { Bulan } & : 10 \% \\ 12 \text { Bulan } & : 10 \%\end{array}$

Sumber: PT. BPR Mapalus Tumetenden Cabang Tomohon

Perhitungan Bunga dan Pajak PPh Final Pasal 4 ayat 2 atas Deposito pada PT. BPR Mapalus Tumetenden Cabang Tomohon

Sampel yang didapatkan dari perusahaan tersebut, perhitungannya dijabarkan sebagai berikut:

1. Ibu A menyimpan dana yang dimilikinya sebesar Rp. 6.500.000,- di BPR Mapalus Tumetenden Cabang Tomohon dalam bentuk Deposito dengan jangka waktu 3 bulan (dimana suku bunga yang ditawarkan 10\%) per tanggal 15 Februari 2016. Bunga yang di dapatkan dapat dihitung :

$$
\begin{aligned}
\text { Bunga Deposito } & =\text { Jumlah Deposito x Suku Bunga } \\
& =\text { Rp. } 6.500 .000 \times 10 \% \\
& =\text { Rp. } \quad 650.000,-
\end{aligned}
$$

PP 131 Tahun 2000, dimana bunga deposito dan tabungan serta diskonto SBI yang nominalnya tidak melebihi Rp. 7.500.000,- dan bukan merupakan jumlah yang dipecah-pecah, TIDAK dikenakan PPh Final Pasal 4 ayat 2.

Bunga yang akan diterima oleh ibu A tiap bulannya:

$$
\begin{aligned}
\text { Bunga Per bulan } & =\text { Rp. } 650.000: 12 \text { bulan } \\
& =\text { Rp. } 54.166,67,-
\end{aligned}
$$

2. Pada tanggal 12 Januari 2016 Ibu B menyimpan dananya dalam bentuk Deposito pada BPR Mapalus Tumetenden Cabang Tomohon sebesar Rp. 50.000.000,- dengan jangka waktu pencairan 6 bulan. Bunga yang di dapatkan dapat dihitung:

$$
\begin{aligned}
\text { Bunga Deposito } & =\text { Jumlah Deposito x Suku Bunga } \\
& =\text { Rp. } 50.000 .000 \times 10 \% \\
& =\text { Rp. } 5.000 .000,-
\end{aligned}
$$

PP 131 Tahun 2000 yaitu atas penghasilan berupa bunga yang berasal dari deposito dan tabungan serta diskonto SBI yang diterima oleh Wajib Pajak dalam negeri dan BUT dikenakan pajak 
penghasilan yang bersifat final. Besarnya PPh yang dipotong adalah $20 \%$ dari jumlah bruto. Dengan perhitungannya:

$$
\begin{aligned}
\text { PPh Pasal } 4 \text { (2) } & =\text { Pendapatan Bunga Bruto x 20\% } \\
& =\text { Rp. 5.000.000 x 20\% } \\
& =\text { Rp. } 1.000 .000,-
\end{aligned}
$$

Jadi, pemdapatan Bunga Netto Deposito Ibu B adalah:

Pendapatan Bunga Netto = Pendapatan Bunga Bruto $-\mathrm{PPh}$ Pasal 4 ayat 2

$$
\begin{aligned}
& =\text { Rp. } 5.000 .000-\text { Rp. } 1.000 .000 \\
& =\text { Rp. } 4.000 .000,-
\end{aligned}
$$

Untuk pendapatan bunga netto tiap bulannya yang masuk ke rekening Ibu B adalah:

Bunga netto perbulan = Bunga netto : Jangka Waktu Pencairan

$=$ Rp. $4.000 .000: 6$

$=$ Rp. $666.667,-$ per bulan

\section{Perhitungan Bunga dan Pemotongan Pajak PPh Final Pasal 4 ayat 2 atas tabungan nasabah pada PT. BPR Mapalus Tumetenden Cabang Tomohon}

Secara umum, ada 3 metode perhitungan bunga tabungan yaitu perhitungan bunga tabungan berdasarkan saldo terendah, saldo rata-rata, dan saldo harian. Beberapa bank menerapkan jumlah hari dalam 1 tahun 365 hari, namun ada pula yang menerapkan jumlah hari bunga 365 hari.

Tabel. 3 Transaksi pada rekening Ibu Ane Bulan Maret 2016

\begin{tabular}{ccrr}
\hline Tanggal & Debet & Kredit & \multicolumn{1}{c}{ Saldo } \\
\hline 06-03-2016 & & Rp. 400.000,- & Rp. 400.000,- \\
$12-03-2016$ & & Rp. 1.200.000,- & Rp. 1.600.000,- \\
18-03-2016 & Rp. 550.000,- & & Rp. 1.050.000,- \\
27-03-2016 & & Rp. 200.000,- & Rp. 1.250.000,- \\
\hline
\end{tabular}

a. Menggunakan Metode Saldo Terendah:

Saldo terendah yakni Rp. 400.000,- dan suku bunga tabungan yang didapat $6 \%$, maka:

Bunga Tabungan $=$ Rp. $400.000 \times 6 \% \times 20: 365$

$=$ Rp. 1.315,-

b. Menggunakan Metode Saldo Rata-rata:

Saldo rata-rata Ibu Ane dapat dihitung:

$\mathrm{SRH}=\{($ Rp. $400.000 \times 6$ 6hari $)+($ Rp. $1.600 .000 \times 6$ 6hari $)+($ Rp. $1.050 .000 \times 9$ 9hari $)+$ (Rp.1.250.000 4hari) $\}: 20$ $=$ Rp. 1.322.500,-

Bunga Tabungan = Rp. $1.322 .500 \times 6 \% \times 20: 365$

$=$ Rp. $4.348,-$

c. Menggunakan Metode Saldo Harian:

Bunga Tabungan $\quad=\{($ Rp. $400.000 \times 6 \% \times 1: 365) \times 6$ hari $\}+$ $\{($ Rp. $1.600 .000 \times 6 \% \times 1: 365) \times 6$ hari $\}+$ $\{($ Rp. $1.050 .000 \times 6 \% \times 1: 365) \times 9$ hari $\}+$ \{(Rp. $1.250 .000 \times 6 \% \times 1: 365) \times 4$ hari $\}$

$=$ Rp. 5.137,-

PP No. 131 Tahun 2000, dimana bunga deposito dan tabungan serta diskonto SBI yang nominalnya tidak melebihi Rp. 7.500.000,- dan bukan merupakan jumlah yang dipecahpecah, TIDAK dikenakan PPh Final Pasal 4 ayat 2. 
Tabel. 4 Transaksi rekening Ibu Diane Bulan April 2016

\begin{tabular}{|c|c|c|c|}
\hline Tanggal & Debet & Kredit & Saldo \\
\hline 01-04-2016 & \multirow{5}{*}{$\begin{array}{l}\text { Rp. } 35.000 .000,- \\
\text { Rp. } 10.000 .000,-\end{array}$} & \multirow{5}{*}{$\begin{array}{l}\text { Rp. } 53.000 .000,- \\
\text { Rp. } 22.000 .000,-\end{array}$} & Rp.50.000.000,- \\
\hline 08-04-2016 & & & Rp.15.000.000.- \\
\hline $10-04-2016$ & & & Rp.68.000.000,- \\
\hline $13-04-2016$ & & & Rp.58.000.000,- \\
\hline $18-04-2016$ & & & Rp.80.000.000,- \\
\hline
\end{tabular}

a. Menggunakan Metode Saldo Terendah:

Saldo terendah yakni Rp. 15.000.000,- dan suku bunga tabungan yang didapat 6\%, maka:

Bunga Tabungan $=$ Rp. $15.000 .000 \times 6 \% \times 20: 365$

$=$ Rp. 49.315,-

Saldo Ibu Diane diatas Rp. 7.500.000, maka Ibu Diane dikenakan pajak PPh Final Pasal 4 ayat 2 dengan tariff pajak $20 \%$, sehingga:

Pajak

$=$ Rp. $49.135 \times 20 \%$

$=$ Rp. 9.863,-

Total Bunga Tabungan bersih yang akan diterima oleh Ibu Diane adalah:

Bunga Bersih = Rp. $49.315-$ Rp. 9.863

$=$ Rp. 39.452,-

b. Menggunakan Metode Saldo Rata-rata:

3hari) +

SRH $=\{($ Rp.50.000.000 $\times$ 7hari $)+($ Rp. $15.000 .000 \times 2$ hari $)+($ Rp.68.000.000 $\times$

$$
\begin{aligned}
& (\text { Rp. } 58.000 .000 \times 5 \text { hari })+(\text { Rp. } 80.000 .000 \times 3 \text { hari })\}: 20 \text { hari } \\
= & \text { Rp. 55.700.000,- }
\end{aligned}
$$

Nilai rata-rata tabungan harian Rp. 50.000.000,- bunga tabungan yang dikenakan 6\% sehingga perhitungan bunga tabungannya adalah:

Bunga $=$ Rp. $55.700 .000 \times 6 \% \times 20 \%: 365$

$=$ Rp. $183.123,-$

PP No. 131 Tahun 2000, dimana saldo yang dimiliki oleh Ibu Diane melebihi Rp. 7.500.000,maka Ibu Diane dikenakan PPh Pasal 4 ayat 2 dengan tarif 20\%, sehingga perhitungannya:

Bunga Kena Pajak = Rp. $183.123 \times 20 \%$

$=$ Rp. 36.624,-

Bunga Bersih = Rp. $183.123-$ Rp. 36.624

$=$ Rp. $146.498,-$

c. Menggunakan Metode Saldo Harian:

$\begin{aligned} \text { Bunga Tabungan } \quad & \{(\text { Rp. } 50.000 .000 \times 6 \% \times 1: 365) \times 7 \text { hari }\}+ \\ & \{(\text { Rp. } 15.000 .000 \times 6 \% \times 1: 365) \times 3 \text { hari }\}+ \\ & \{(\text { Rp. } 68.000 .000 \times 6 \% \times 1: 365) \times 3 \text { hari }\}+ \\ & \{(\text { Rp. } 58.000 .000 \times 6 \% \times 1: 365) \times 5 \text { hari }\}+ \\ & \{(\text { Rp. } 80.000 .000 \times 6 \% \times 1: 365) \times 3 \text { hari }\} \\ = & \text { Rp. } 188.562,-\end{aligned}$

PP No. 131 Tahun 2000 , dimana saldo tabungan yang dimiliki oleh Ibu Diane adalah senilai Rp.80.000.000,- melebihi Rp. 7.500.000,- maka dikenakan PPh Final Pasal 4 ayat 2 dengan tarif pajak $20 \%$. Perhitungan pajaknya adalah:

PPh Pasal 4 ayat $2=$ Rp. $188.562 \times 20 \%$

$=$ Rp. 37.712,2 
Bunga Bersih

$$
\begin{aligned}
& =\text { Rp. } 188.562-\text { Rp. } 37.712,2 \\
& =\text { Rp. } 150.849,6
\end{aligned}
$$

Pemotongan PPh Final tersebut dilakukan oleh pihak PT. BPR Mapalus Tumetenden Cabang Tomohon dengan melakukan pemotongan secara otomatis oleh sistem komputerisasi pada rekening tabungan nasabah tersebut setiap bulannya.

\section{Penyetoran dan Pelaporan PPh Final Pasal 4 ayat 2 atas Bunga Deposito dan Tabungan Nasabah pada PT. BPR Mapalus Tumetenden Cabang Tomohon}

Sejak awal tahun 2015 penyetoran PPh Final Pasal 4 ayat 2 atas bunga deposito dan tabungan nasabah pada PT. BPR Mapalus Tumetenden Cabang Tomohon telah menggunakan sistem pembayaran pajak secara elektronik (Billing system) sehingga penyetoran menjadi lebih mudah, lebih cepat dan lebih akurat. Penyetoran PPh Final Pasal 4 ayat 2 dilakukan paling lambat tanggal 10 bulan takwin setelah bulan saat terutangnya pajak. Dalam pelaporannya, SPT Masa ini dilampiri dengan daftar bukti pemotongan dan cetak bukti penerimaan Negara sebagai ganti SSP. Pelaporan tersebut dilakukan PT. BPR Mapalus Tumetenden Cabang Tomohon setiap sebelum tanggal 20 bulan takwin.

\section{Pembahasan}

Hasil penelitian yang dilakukan pada PT. BPR Mapalus Tumetenden Cabang Tomohon mengenai perhitungan dan pelaporan PPh Final Pasal 4 ayat 2 didapatkan hasil melalui perhitungan sampel transaksi rekening beberapa nasabah yaitu metode perhitungan bunga tabungan yang digunakan oleh BPR Mapalus Tumetenden adalah metode perhitungan bunga berdasarkan saldo harian. Bunga tabungan akan dihitung otomatis oleh sistem dan disalurkan langsung kepada rekening tiap nasabah setiap bulannya, sesuai dengan perhitungan yang ada. Tarif pajak yang dikenakan berdasarkan dengan UU No. 36 Tahun 2008 dan PP No. 131 Tahun 2000 ialah $20 \%$ dari jumlah bruto. Tarif ini dikenakan ketika jumlah tabungan atau deposito nasabah melebihi Rp. 7.500.000,- dan bukan merupakan nilai yang terpecah-pecah. Pelaporan PPh Final Pasal 4 ayat 2 atas bunga deposito dan tabungan nasabah pada PT. BPR Mapalus Tumetenden cabang Tomohon dilaporkan tiap bulannya melebihi rekening Giro paling lambat tanggal 10 pada bulan berikutnya.

\section{Kesimpulan}

\section{PENUTUP}

1. Perhitungan bunga tabungan pada PT. BPR Mapalus Tumetenden Cabang Tomohon menggunakan metode perhitungan saldo harian yang dihitung oleh sistem secara otomatis pada rekening nasabah.

2. Perhitungan, penyetoran, dan pelaporan PPh Final Pasal 4 ayat 2 atas bunga deposito dan tabungan nasabah pada PT. BPR Mapalus Tumetenden Cabang Tomohon, dilakukan langsung oleh PT. BPR Mapalus Tumetenden secara online, dan terkait hal perhitungan dan pelaporannya telah sesuai dengan Peraturan Pemerintah yang ada yaitu PP No. 131 Tahun 2000 tentang Pajak Penghasilan dan UU No. 36 Tahun 2008 tentang Pajak Penghasilan Pasal 4 ayat 2.

\section{Saran}

1. Lebih baik lagi dari segi layanan guna memuaskan nasabah baik pinjaman ataupun simpanan.

2. Lebih teliti lagi dalam perhitungan, pemotongan, serta pelaporan PPh Final Pasal 4 ayat 2 atas bunga deposito dan tabungan nasabah.

3. Lebih di perhatikan dan diteliti lagi dalam memberikan nilai sku bunga baik deposito maupun tabungan dan sesuaikan dengan BI Rate yang ada.

4. Untuk penelitian selanjutnya diharapkan dapat lebih diperluas lagi, tidak hanya pada perhitungan dan pelaporan PPh Final Pasal 4 ayat 2 untuk bunga deposito dan tabungan. 
DAFTAR PUSTAKA

Adriani. 2011. Penagihan Pajak: Pajak Pusat dan Pajak Daerah. Bogor: Ghalia Indonesia.

Basirun. 2009. Jenis-jenis Penelitian. Gombong, Jawa Tengah.

Hakim, Fadli. 2015. Analisis Penerapan PP No. 4 Tahun 2013 tentang Pajak Penghasilan UMKM

Terhadap Tingkat Pertumbuhan Wajib Pajak dan Penerimaan PPh Pasal 4 ayat 2 pada KPP

Pratama Manado. FEB Unsrat, Manado. Jurnal Emba.

Harnanto. 2013. Perencanaan Pajak. Cetakan Pertama. BPFE, Yogyakarta.

Herduard R. Homenta. 2015. Perhitungan, Pemotongan, Pencatatan dan Pelaporan Pajak Penghasilan Pasal

21 pada CV. Multi Karya Utama. Universitas Sam Ratulangi, Manado. Jurnal Emba.

Hery. 2013. Teori Akuntansi Suatu Pengantar. Lembaga Penerbit FE. Universitas Indonesia, Jakarta.

Mardiasmo. 2011. Perpajakan. Edisi Revisi, Andi, Yogyakarta.

Mokoagow, Wita Wardani. 2015. Analisis Perhitungan PPh Final Pasal 4 ayat 2 atas Bunga Deposito dan Tabungan Nasabah pada PT. Bank Sulut Cabang Kotamobagu. FEB Unsrat, Manado. Jurnal EMBA.

Soeratno, Lincoln. 2008. Metodologi Penelitian Untuk Ekonomi dan Bisnis. Edisi Revisi. UPP STIM YKPN, Yogyakarta.

Sukrisno, Agoes. 2010. Akuntansi Perpajakan. Edisi 2 Revisi, Salemba Empat, Jakarta.

Supriyanto, Eddy. 2011. Akuntansi Perpajakan. Edisi Pertama. Graha Ilmu, Yogyakarta. 